\title{
ANALISA DAN PERANCANGAN SISTEM INFORMASI KEBUTUHAN ATAP BAJA RINGAN BERBASIS VB.NET PADA CV. ARTHA TRUSS
}

\author{
Didi Sunardi ${ }^{1}$ Karya Suhada ${ }^{2}$ \\ E-mail : ${ }^{1}$ didi.sunardi83@gmail.com, ${ }^{2}$ karyasuhada@gmail.com
}

\begin{abstract}
Abstrak
Teknologi adalah proses yang meningkatkan nilai tambah, proses tersebut menggunakan atau menghasilkan suatu produk, produk yang dihasilkan tidak terpisah dari produk lain yang telah ada, dan karena itu menjadi bagian integral dari suatu sistem. CV. ARTHA TRUSS adalah perusahaan penyedia atap baja ringan. Kajian ini bertujuan membuat suatu sistem mengenai Pengolahan Data dan informasi mengenai perhitungan kebutuhan atap baja ringan. Pada CV. ARTHA TRUSS, sistem perhitungan kebutuhan atap baja ringan masih belum terkomputerisasi. Oleh sebab itu penulis mengusulkan sistem perhitungan kebutuhan atap baja ringan secara terkomputerisasi. Sistem ini dibuat dengan menggunakan perangkat lunak Microsoft Visual Studio 2008 dan SQL Server 2005. Dengan adanya sistem ini bertujuan untuk memberikan kemudahan kepada penggunanya dalam pengolahan data dan informasi perhitungan kebutuhan atap baja ringan sehingga dapat lebih efisien dan efektif.
\end{abstract}

Kata Kunci : Perhitungan kebutuhan atap baja ringan, Microsoft visual studio 2008 dan SQL Server 2005

\begin{abstract}
Technology is a process that increases the added value, the process uses or produces a product, the product is not apart from other products that have been there, and therefore an integral part of a system. CV. ARTHA TRUSS is a provider of lightweight steel roof. this study aims to create a system of the Processing Data and information regarding calculation of lightweight steel roofing needs. At the CV. ARTHA TRUSS, the calculation system of lightweight steel roofing needs still not computerized. Therefore, the authors propose a system lightweight steel roof requirement calculations are computerized. The system is made using the software Microsoft Visual Studio 2008 and SQL Server 2005. With this system aims to provide convenience to users in data processing and calculation of required information steel roof light so it can be more efficient and effective.
\end{abstract}

Keywords: Calculation of lightweight steel roofing, microsoft visual studio 2008 and SQL Server 2005 


\section{PENDAHULUAN}

\section{Latar Belakang}

Perkembangan ilmu pengetahuan dan teknologi yang sangat pesat telah membawa perubahan yang besar dalam kehidupan manusia. Dunia pendidikan khususnya yang merupakan salah satu pilar utama yang membawa perubahan tersebut. Dengan semakin berkembangnya ilmu pengetahuan dan teknologi saat ini, maka bermunculan media-media yang dapat digunakan sebagai media pengolahan data, penyaji atau penyampai informasi, hal ini dikarenakan informasi sangat berharga dan mahal harganya.

Tataran perusahaan yang bergerak di bidang penyedia atap baja ringan membutuhkan suatu sistem penghitungan kebutuhan atap baja ringan yang baik. Keadaan tersebut menyebabkan banyaknya perusahaan yang meningkatkan pengembangan dibidang penghitungan atap baja ringan untuk meningkatkan pelayanan yang lebih baik lagi dan dapat mengolah data dengan mudah, cepat dan akurat.

Berdasarkan permasalahan yang terjadi saat ini pada CV. ARTHA TRUSS maka perusahhan berusaha menyajikan sistem informasi kebutuhan atap baja ringan kepada pelanggan secara cepat dan tepat.

CV. ARTHA TRUSS masih belum menggunakan komputerisasi dalam sistem penghitungan kebutuhan atap baja ringan, dimana dalam melakukan perhitungan kebutuhan atap baja ringan masih menggunakan curat-coret pada kertas. Untuk menghitung kebutuhan atap baja ringan diperlukan rumus yang lumayan susah sehingga terjadi kesalahan-kesalahan perhitungan yang kurang akurat dan waktu yang cukup lama dalam pengolahannya. Oleh sebab itu penulis berkeinginan untuk merancang "Analisa Dan Perancangan Sistem Informasi Kebutuhan Atap Baja Ringan Berbasis Vb.Net Pada CV. ARTHA TRUSS".

\section{TINJAUAN PUSTAKA}

\section{Pengertian Kebutuhan}

Menurut Henry Murray dan Alwisol (2007:218), "Kebutuhan adalah sebuah konstruk yang menunjukkan "sebuah dorongan dalam wilayah otak" yang mengatur berbagai proses seperti persepsi, pikiran, dan tindakan dengan maksud untuk mengubah kondisi yang ada dan tidak memuaskan. Sebuah kebutuhan dapat diakibatkan oleh proses internal namun lebih dari sepuluh distimulasi oleh factor lingkungan. Secara umum, sebuah kebutuhan disertai oleh perasaan tertentu atau emosi dan ia memiliki sebuah cara khusus mengekspresikan dirinya dalam mencapai pemecahannya".

Menurut Abraham Maslow dan Slamet Santoso (2010:111), "Kebutuhan yang menyebutkan bahwa tingkah laku individu berguna untuk memenuhi kebutuhannya, dimana teori ini mempunyai empat prinsip landasan, juga mengungkapkan teori yakni:

1. Manusia adalah binatang yang berkeinginan

2. Kebutuhan manusia tampak terorganisir dalam kebutuhan yang bertingkat-tingkat

3. Bila salah satu kebutuhan terpenuhi, kebutuhan lain akan muncul.

4. Kebutuhan yang telah terpenuhi tidak mempunyai pengaruh, dan kebutuhan lain yang lebih tinggi menjadi dominan ".

\section{Pengertian Baja Ringan}

Menurut Wildensyah (2007:2), "Baja ringan adalah baja canai dingin yang keras yang diproses kembali komposisi atom dan molekulnya, sehingga menjadi baja yang lebih fleksibel". Baja ringan masuk ke Indonesia tahun 1993 dibawah PT. Pryda Australia yang membawa system rangka atap kayu. Kemudian tahun 2003 berinovasi dan beralih teknologi menjadi rangka atap baja ringan.

Bahan dasar baja ringan adalah Carbon Steel. Carbon Steel adalah baja yang terdiri dari elemen-elemen yang prosentase maksimum selain bajanya sebagai berikut : $1.70 \%$ Carbon, $1.65 \%$ Manganese, $0.60 \%$ Silikon, $0.60 \%$ Copper. Carbon adalah unsur kimia dengan nomor atom 6, tingkat oksidasi 4.2 dan mangan adalah unsur kimia dengan nomor atom 25, tingkat oksidasi 7.6423. Carbon dan Manganese adalah bahan pokok untuk meninggikan tegangan (strengh) dari baja murni.

Menurut Renansiva (2006:2), Rangka atap baja ringan yang diproduksi di Indonesia menggunakan bahan dasar baja dengan kekuatan G-550 Mpa atau setara dengan $5500 \mathrm{~kg} / \mathrm{cm} 2$ sesuai standar AISI (American Iron and Steel Institute). Adapun coating (pelapis/pelindung) 
baja ringan dari karat yang beredar adalah zinc/galvanis, zincalume, dan zincalume dengan penambahan magnesium. Lapisan coating ini melindungi baja ringan dari karat".

\section{Pengertian Perancangan}

Menurut Jogiyanto (2010:62), "Perancangan merupakan kegiatan untuk membentuk membuat sketsa struktur kegiatan atau pekerjaan dari suatu analisis ke dalam suatu perencanaan untuk dapat diterapkan dalam suatu bentuk nyata".

\section{Rumus Menghitung Kebutuhan Atap Baja Ringan}

Menghitung kebutuhan atap baja ringan diperlukan rumus yang lumayan susah, penulis mendapatkan rumus tersebut dari pemilik CV. ARTHA TRUSS. Adapun rumusnya sebagai berikut :

1. Menghitung luas atap Panjang * lebar / 0,866 ( rumus mutlak atau $\cos 30$ )

2. Menhitung overstack Overstack * 2

3. Menghitung panjang rumah Panjang + overstack

4. Menghitung lebar rumah Lebar + overstack

5. Menghitung jumlah kuda-kuda Panjang / 1,2 (Rumus mutlak)

6. Menghitung tinggi segitiga/gewel 1/3* panjang Rumah

7. Menghitung sisi miring ((gewel*gewel) + $(1 / 2 *$ lebar* $1 / 2$ lebar $))=\sqrt{ }$ sisi miring $=$ sisi miring.

8. Menghitung jumlah canal kuda-kuda $(($ jumlah kuda-kuda $*$ sisi miring $) * 2)+$ (lebar * jumlah kuda-kuda) + (jumlah kuda-kuda * 14) / 6) rumus mutlak.

9. Menghitung harga canal kuda-kuda Jumlah canal kuda-kuda * harga canal.

10. Menghitung jumlah canal atap Luas atap / 1,53 rumus mutlak.

11. Menghitung harga canal atap Jumlah canal atap * harga canal.

12. Menghitung jumlah genteng Luas atap / 1,62 rumus mutlak.

13. Menghitung harga genteng Jumlah genteng $*$ harga genteng.

14. Menghitung jumlah reng Luas atap / 1,17 rumus mutlak.

15. Menghitung hrga reng Jumlah reng* harga reng

16. Menghitung jumlah nok

Panjang rumah $* 0,8$ rumus mutlak.

17. Menghitung harga nok

Jumlah nok * harga nok

18. Menghitung jumlah baut reng

Luas atap * 25 rumus mutlak

19. Menghitung harga baut reng

Jumlah baut reng * harga baut

20. Menghitung jumlah baut genteng

Luas atap * 20 rumus mutlak

21. Menghitung harga baut genteng

Jumlah baut genteng * harga baut

22. Menghitung jumlah dinabolt

Panjang rumah $* 4$ rumus mutlak

23. Menghitung harga dinabolt

Jumlah dinabolt * harga dinabolt

24. Menghitung jasa pasang

Jasa pasang * luas atap

25. Menghitung jasa pasang

Jasang $=$ Val (txtluvoltap.Text $) * 150000$

26. Menghitung Total

Total $=(($ henalkud + hcanal + hgenteng + hreng + hnok + hbautreng + hbautgenteng + hdinabolt + jasang + Val (txtppn.Text) $)-$ discount)

27. Menghitung PPN

txtppn.Text $=$ total $* 10 / 100$

28. Menghitung Discount

Discount $=$ total $*($ Val $($ txtdisc.. Text $) / 100)$

29. Menghitung Biaya material

bmaterial $=$ hcnalkud + hcanal + hgenteng

+ hreng + hnok + hbautreng +hbautgenteng

+ hdinabolt

30. Menghitung Sisa

Total - Bayar DP

\section{METODE PENELITIAN}

Metodologi perancangan sistem yang digunakan penulis dalam pengembangan sistem yaitu metodologi waterfall model. Metode ini sering digunakan oleh penganalisa sistem pada umumnya. Inti dari metode waterfall adalah pengerjaan dari suatu sistem dilakukan secara 
berurutan atau secara linear. Secara garis besar metode waterfall mempunyai langkah-langkah sebagai berikut :

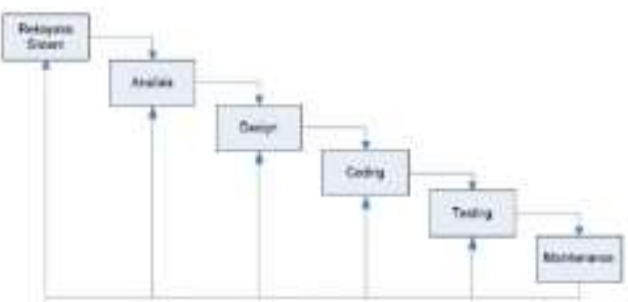

Gambar 1. Waterfall Model

1. Analisa, langkah ini merupakan analisa terhadap kebutuhan sistem. Pengumpulan data dalam tahap in bisa melakukan sebuah penelitian, wawancara, atau studi literatur. Seorang sistem analis akan menggali informasi sebanyak-banyaknya dari user sehingga akan tercipta sebuah sistem komputerisasi yangb bisa melakukan tugastugas yang diinginkan user tersebut.

2. Desain, proses desain akan menterjemahkan syarat kebutuhan ke sebuah perancangan perangkat lunak yang diperkirakan sebelum dibuat coding. Proses ini berfokus pada struktur data, arsitektur perangkat lunak, representasi interface, dan detail (algoritma) procedural. Tahapan ini akan menghasilkan dokumen yang disebut software requirement. Dokumen inilah yang akan digunakan untuk melakukan aktifitas pembuatan sistemnya.

3. Coding, coding merupakan penerjemahan desain dalam bahasa yang bisa dikenali oleh komputer. Dilakukan oleh programmer yang akan menterjemahkan transaksi yang diminta oleh user. Tahapan inilah yang merupakan tahapan secara nyata dalam mengerjakan suatu sistem.

4. Testing, Setelah pengkodean selesai maka akan dilakukan testing terhadap sistem yang telah dibuat. Tujuan testing adalah menemukan kesalahan-kesalahan terhadap sistem tersebut dan kemudian bisa diperbaiki.

5. Penerapan, tahapan in bisa dikatakan final dalam pembuatan sistem. Setelah melakukan analisa, desain, dan pengkodean maka sistem yang sudah jadi akan digunakan oleh user.

6. Pemeliharaan, perangkat lunak yang sudah disampaikan kepada user pasti akan mengalami perubahan. Perubahan tersebut bisa karena mengalami kesalahan karena pernagkat lunak harus menyesuaikan dengan lingkungan (peripheral atau sistem operasi baru) baru, atau user membutuhkan perkembangan fungsional.

\section{DFD Konteks}

Diagram konteks (Context Diagram) adalah Suatu diagram yang menggunakan notasi-notasi untuk menggambarkan arus dari data pada suatu system, yang penggunaannya sangat membantu untuk memahami system secara logika, terstruktur dan jelas. Berikut Diagram Konteks yang diusulkan :

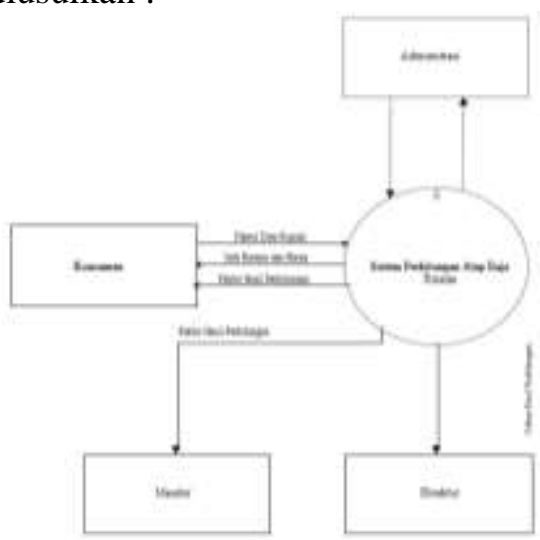

Gambar 2. DFD Konteks Kebutuhan Atap Baja Ringan

\section{Diagram Overview}

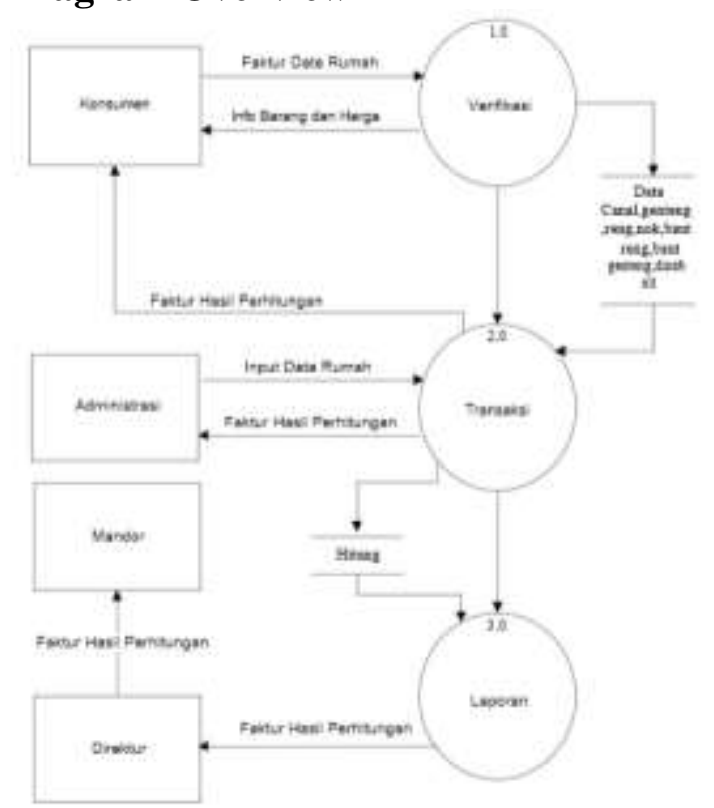

Gambar 3. Diagram Overview Kebutuhan Atap Baja Ringan 
ERD

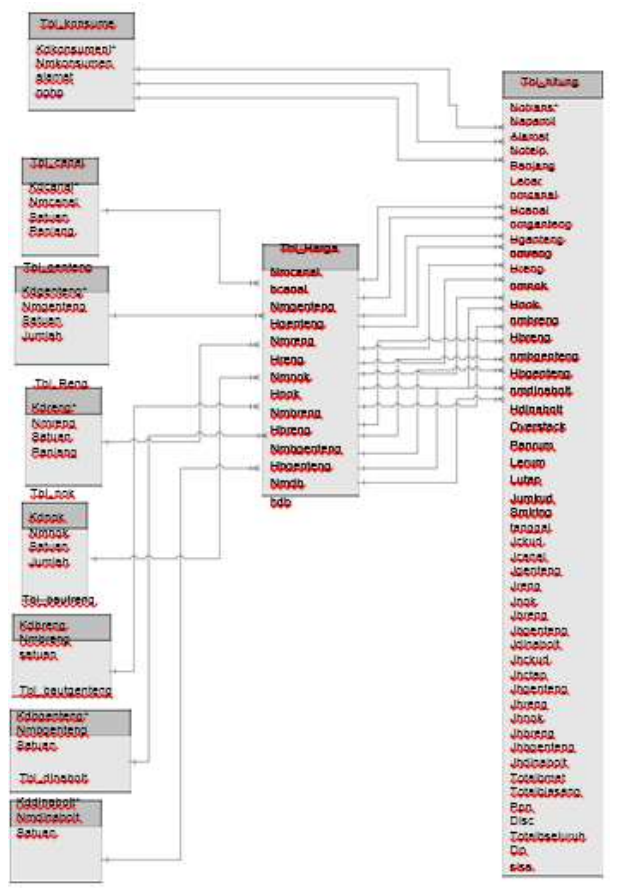

Gambar 4. ERD Kebutuhan Atap Baja Ringan

\section{HASIL DAN PEMBAHASAN}

\section{Form Login}

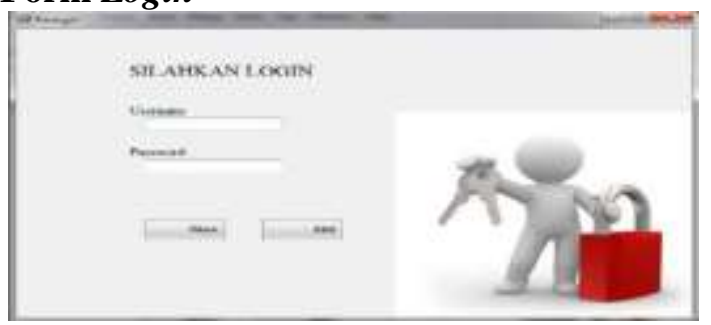

Gambar 5. Form Login

Keterangan : Menu login ini untuk masuk ke dalam sistem, dan ada satu user untuk bisa mengakses sistem, yaitu admin. Tetapi ketika ditambah user login ini bisa mengakses sistem.

\section{Form Menu Utama}

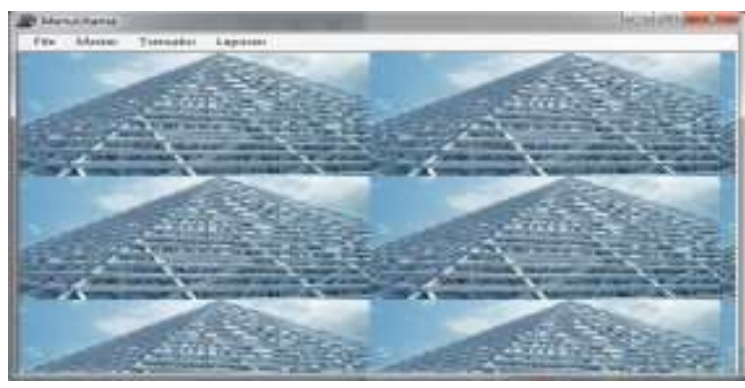

Gambar 6. Form Menu Utama
Keterangan : Menu ini untuk menampilkan semua menu yang muncul pada user admin, dan untuk keluar dari sistem ini bisa mengklik File lalu keluar.

\section{Form Masukan User}

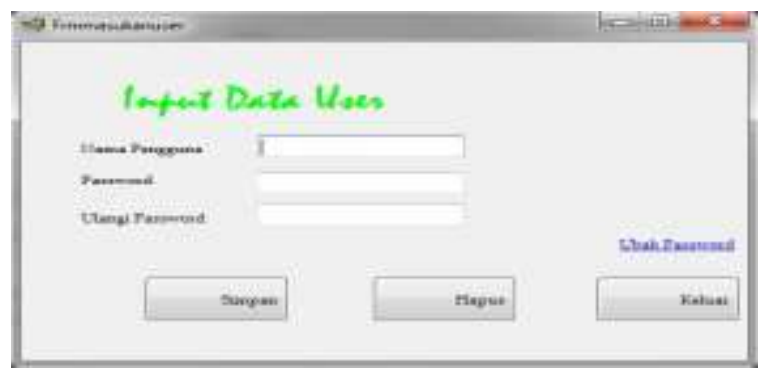

Gambar 7. Form Masukan User

Keterangan : Menu Masukan User ini untuk memasuk pengguna baru ke dalam sistem.

\section{Form Ubah Password}

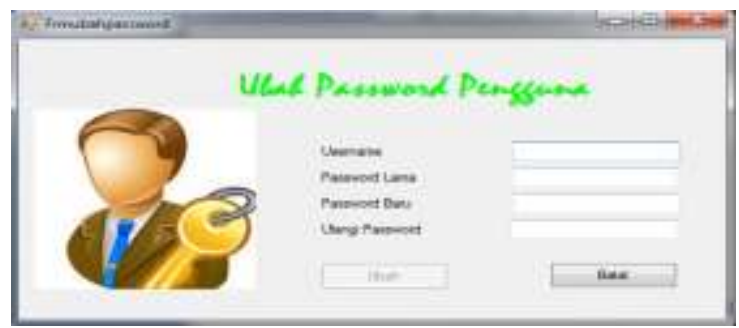

Gambar 8. Form Ubah Password

Keterangan : Menu Masukan User ini untuk memasuk pengguna baru ke dalam sistem.

\section{Form Master Canal}

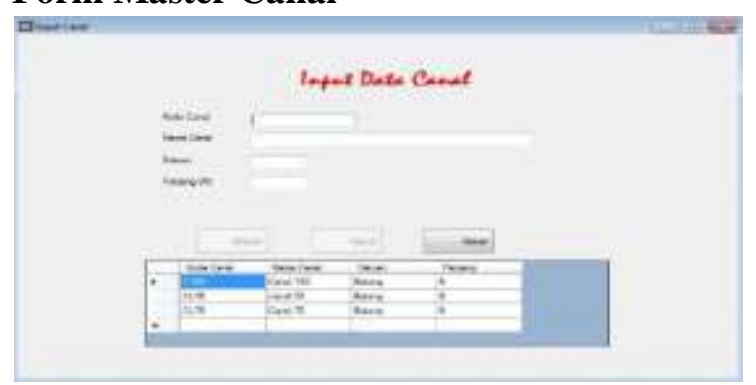

Gambar 9. Form Master Canal

Keterangan : Menu Master Canal ini untuk memasuk Data Canal ke dalam sistem. 


\section{Form Master Genteng}

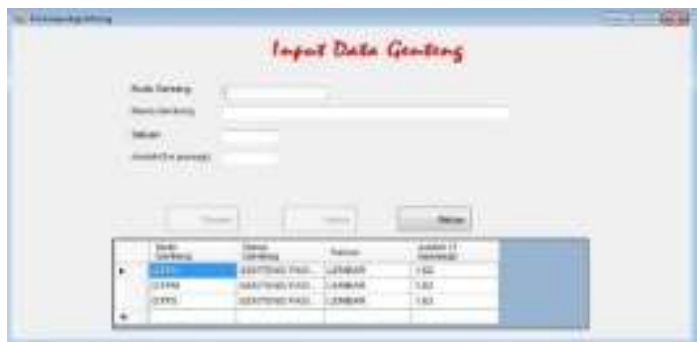

Gambar 10. Form Master Genteng

Keterangan : Menu Master Genteng ini untuk memasuk Data Genteng ke dalam sistem.

\section{Form Master Reng}

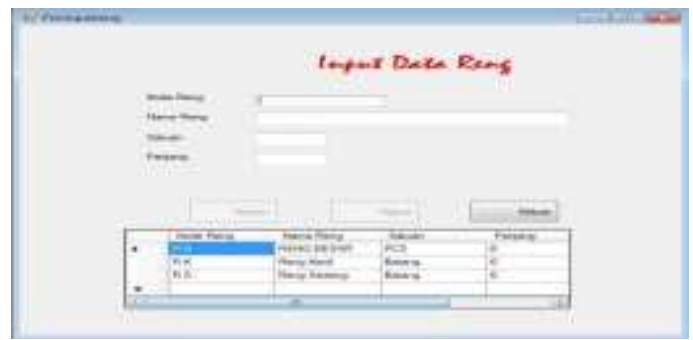

Gambar 11. Form Master Reng

Keterangan : Menu Master Reng ini untuk memasuk Data Reng ke dalam sistem.

\section{Form Master Nok}

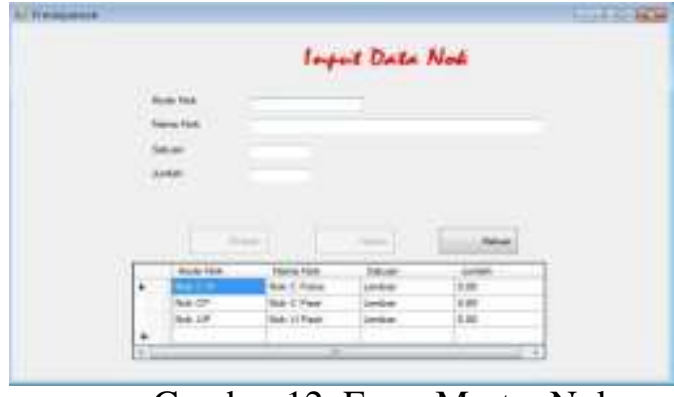

Gambar 12. Form Master Nok

Keterangan : Menu Master Nok ini untuk memasuk Data Nok ke dalam sistem.

\section{Form Master Baut Reng}

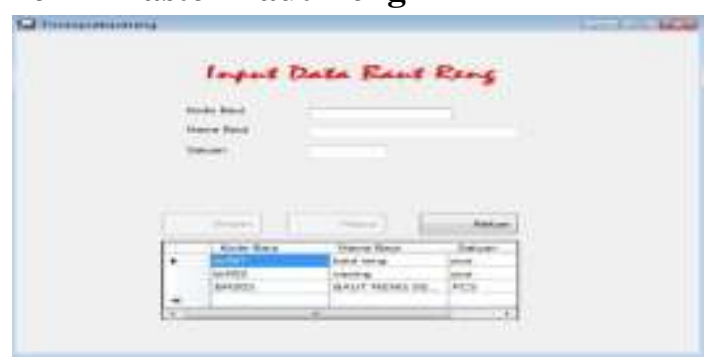

Gambar 13. Form Master Baut Reng
Keterangan : Menu Master Baut Reng ini untuk memasuk Data Baut Reng ke dalam sistem.

\section{Form Master Baut Genteng}

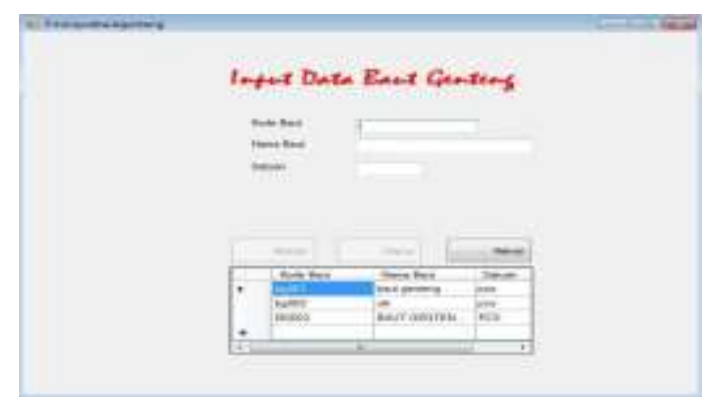

Gambar 14. Form Master Baut Genteng

Keterangan : Menu Master Baut Genteng ini untuk memasuk Data Baut Genteng ke dalam sistem.

\section{Form Master Dinabolt}

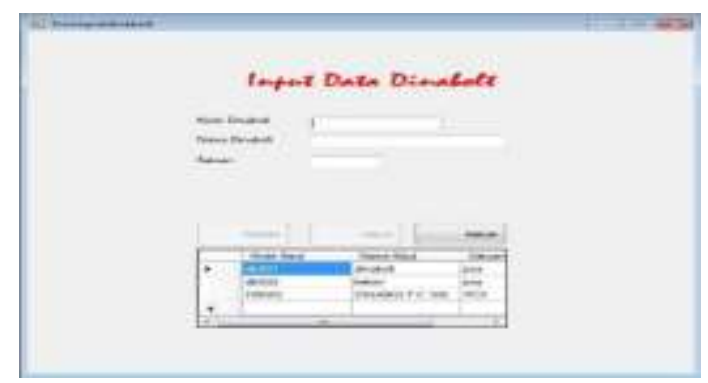

Gambar 15. Form Master Dinabolt

Keterangan : Menu Master Dinabolt ini untuk memasuk Data Dinabolt ke dalam sistem.

\section{Form Master Konsumen Tetap}

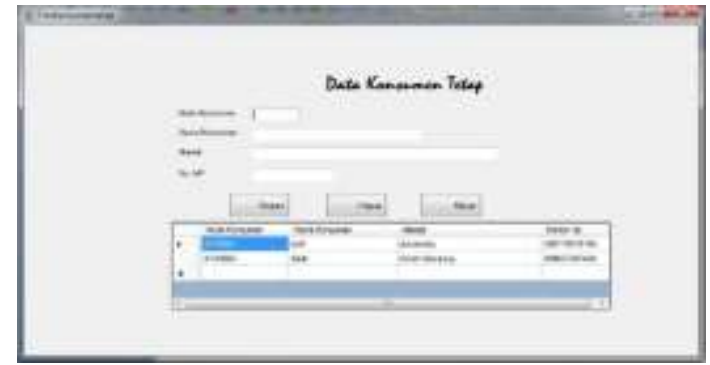

Gambar 16. Form Master Konsumen Tetap

Keterangan : Menu Master Konsumen Tetap ini untuk memasuk Data Konsumen Tetap ke dalam sistem. 


\section{Form Daftar Harga}

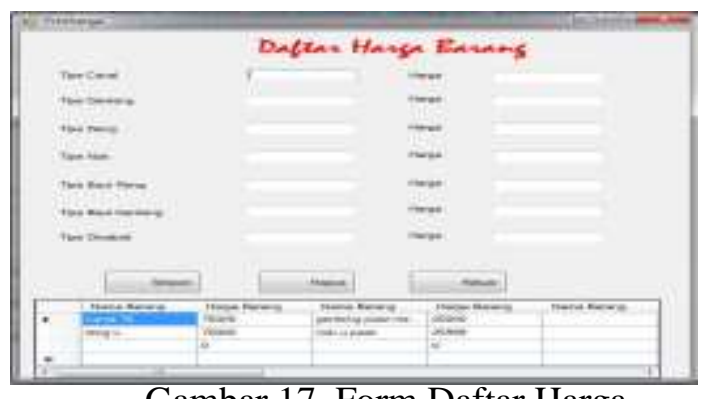

Gambar 17. Form Daftar Harga

Keterangan : Menu Daftar Harga Tetap ini untuk memasuk Daftar Harga ke dalam sistem.

\section{Form Hitung}

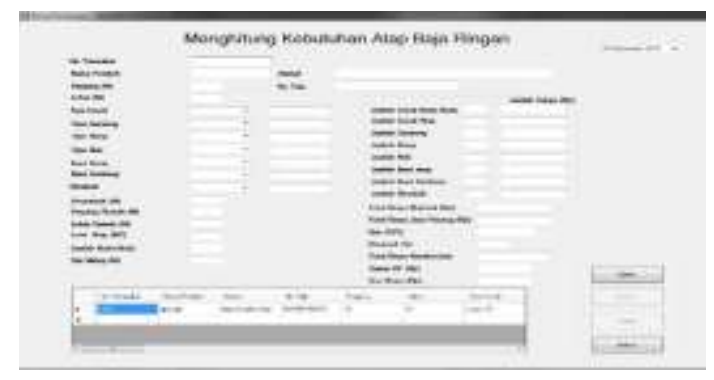

Gambar 18. Form Transaksi Perhitungan

Keterangan : Menu Transaksi Perhitungan ini peroses perhitungan oleh sistem.

\section{KESIMPULAN DAN SARAN}

\section{Kesimpulan}

Adanya sistem perhitungan kebutuhan atap baja ringan dengan berbasis visual maka sistem ini diharapkan mampu mengatasi masalahmasalah pada sistem yang lama, serta mampu menghasilkan informasi yang berkualitas sehingga dapat membantu pihak-pihak yang terkait dalam mengambil keputusan. Dari uraian perancangan sistem informasi perhitungan kebutuhan atap baja ringan berbasis visual di CV. ARTHA TRUSS, maka dapat diambil kesimpulan:

1. Sistem ini memudahkan pengguna untuk melakukan perhitungan serta memberikan informasi Biaya bagi Konsumen.

2. Sistem ini menyimpan seluruh transaksi perhitungan kebutuhan atap baja ringan sehingga pihak pimpinan dalam hal ini Direktur dapat memantau transaksi perhitungan.

3. Sistem ini lebih memudahkan dalam proses pencarian data-data yang dibutuhkan.

4. Dengan adanya sistem ini, Direktur tidak perlu susah untuk menghitung kebutuhan atap baja ringan secara manual.

5. Dengan adanya sistem ini, perusahaan dapat meminimalkan penggunaan kertas yaitu kertas untuk menghitung kebutuhan atap baja ringan.

\section{Saran}

Adapun saran untuk pengembangan sistem ini nantinya antara lain:

1. Untuk pengembangan selanjutnya terhadap sistem informasi perhitungan kebutuhan atap baja ringan ini dapat ditambahan fitur-fitur yang bisa menunjang teknologi pada program ini, untuk menjadi lebih baik dan lebih praktis.

2. Tampilan sistem ini dapat dikembangkan untuk menjadi lebih baik lagi, misalnya dengan tampilan yang lebih menarik namun juga tetap sederhana pengoperasiannya, sehingga memudahkan pengguna yang masih awam teknologi dalam mengoperasikannya meski tanpa instruktur.

3. Diperlukan peningkatan sumber daya manusia yang berkualitas dan perangkat komputer yang memadai.

4. Petugas khusus yang diberi tanggung jawab menangani sistem ini, sebaiknya terlebih dulu diberikan petunjuk dan pelatihan pengoperasiannya agar nantinya aplikasi ini dapat bejalan secara maksimal.

5. Suatu sistem akan berjalan dengan baik dan lancar apabila dipelihara dan dikontrol dengan sebaik-baiknya.

\section{DAFTAR PUSTAKA}

Alwisol. 2005. Psikologi Kepribadian. Malang: UMM Press

Maslow, Abraham. 2010. Motivasi dan kepribadian. Jakarta : Midas Surya grafindo.

Renansiva, Revi .2006. Sekilas Tentang Baja Ringan. PT. Jaindo Metal Industries.

Wildensyah, Iden. 2007. Sisi Lain Arsitektur Teknik Sipil dan Lingkungan. Bandung: Alfabet

Jogiyanto, 2010. Analisis dan Desain Sistem Informasi, Edisi IV, Andi Offset, Yogyakarta. 